\title{
Feedrate Optimization for 2.5D Milling Operations
}

\section{Branko Kokotovic}

Assistant Professor University of Belgrade

Faculty of Mechanical Engineering

Nikola Vorkapic

Teaching Assistan

University of Belgrade

Faculty of Mechanical Engineering

Presented research is focused on CNC milling operations of planar contours with flat end mills. Paper presents a set of functions requred for processing the workpiece model and NC part program in order to reconstruction the instantneous area of workpiece engaged by the tool. A Z-map interpretation of workpiece was chosen. Reconstructed engagement map, with previously obtained specific cutting forces, is enough for prediction of instantaneous and representative milling forces in points of programmed toolpath. Further, in order to maintain a specified level of milling force, the correction of the feedrate in toolpath points and then rediscretization of the path is enabled. Paper presents an example of experimental identification of speciffic cutting forces and the results of applications of the procedures, developed in Matlab, for optimization of feedrates. Results obtained through experiments are used for discussion of advantages and limitations of applied models.

\section{Keywords: CNC milling, cutting forces, feedrate optimization}

\section{INTRODUCTION}

Permanent effort in developing of the virtual machining environment [1] assumes implementation of specific functions which are directed to creating of $\mathrm{NC}$ programs for machining, more efficient and more reliable, with full respect of process physics.

In that sense, significant results were reached in commercial CAM systems in recent years. Key feature of such systems is the toolpath generation and selection of machining data that results in more or less constant level of cutting force along the toolpath. In rough milling operations this goal is achieved through specific strategies of toolpath generation (adaptive roughing, morphed spiral pocketing, trochoidal path, corner slicing etc.). In case of finish milling, machining with constant cutting forces can be realized using specific function - feedrate scheduling along the toolpath. Due to the efficacy of software, applied analytic models are mostly based on presumption of strong correlation between cutting force and material removal rate (MRR), which can be estimated relatively simply, by processing of CAD model of machined part in subsequent points of the toolpath.

On the other hand, in many research centers, significant results were achieved in development of the models for optimization of the feedrate, based on different goal functions [2-4]. Most of them use maintaining the predefined level of the cutting force as an optimization criterion, regarding the great importance of cutting forces on machining effects.

Developing of procedure for feedrate optimization includes several issues: model of the cutting forces (i),

Received: January 2019, Accepted: April 2019

Correspondence to: Dr Branko Kokotovic, Assistant

Professor, Faculty of Mechanical Engineering,

Kraljice Marije 16, 11120 Belgrade 35, Serbia

E-mail: bkokotovic@mas.bg.ac.rs

doi: $10.5937 /$ fmet1903613K

(C) Faculty of Mechanical Engineering, Belgrade. All rights reserved model of the workpiece and set of routines for its processing (ii), set of routines for processing $\mathrm{NC}$ part program (iii), model for feedrate adaptation in discrete points of the toolpath (iv) and model for fine tuning of the feedrate along the toolpath (v).

Two models for prediction of cutting forces are widely used: mechanistic [5-7] and experimental [8], [9]. Mechanistic approach has the great flexibility: limited time required for calibration and wide use for different tool shapes and machining methods [10-14]. Influence of the cutter runout on instantaneous uncut chip thickness, in force models, was considered in [15], [16].

Different workpiece models were used for extraction of cutter workpiece engagement (CWE) map, required for application of force model [17-19].

Successful results of integration of workpiece model, cutting force model and set of specific routines for processing of the workpiece model and NC-code, in order to perform feedrate optimization for milling operations, was reported in number of papers [2-5,17, [20,21].

\section{FEEDRATE ADAPTATION AND FEEDRATE OPTIMIZATION}

Dynamic nature of milling forces is the reason for introduction terms like instantaneous cutting forces and representative cutting force. An example with four components of cutting forces for 4-flute end mill for certain cutting data, obtained through simulation, are shown on Figure 1. Graph is referring to one spindle revolution. Lines on graph show dynamic changes of instantaneous values of each force component. Based on these instantaneous values, it is possible to identify representative values of each force component as its minimum or maximum values, during one spindle revolution. For this example, these values are also shown on Figure 1.

In this paper, the term feedrate scheduling is treated as a process which is performed through two procedures: feedrate adaptation and feedrate optimization. In order to 
make a clear difference betweeen these two terms, Figure 2 will be used. Shaded surfaces present pricipal distribution of representative value of particular milling force component $\left(F_{\mathrm{xy}, \max }\right.$, for example), for certain feed per tooth and certain axial depth of cut, as a function of the start and exit angle of rectangular CWE map.

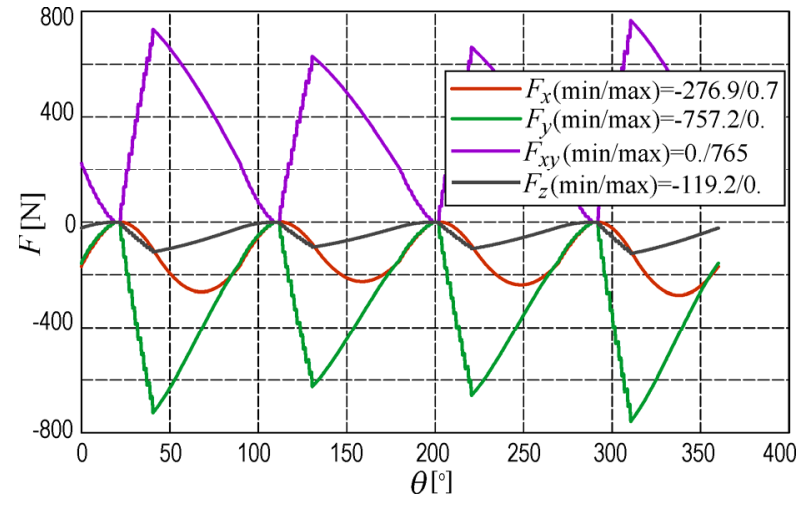

Figure 1. Instantaneous milling forces and representative milling forces

Two examples are referring to up milling (a) and slot milling (b). In both cases, change of radial depth of cut implies change of representative force along trajectories between points $\mathrm{S}$ and $\mathrm{E}$ on surface $F_{\mathrm{xy}}$. Such graph can be constructed for different values of feed per tooth that result in family of surfaces, shown in Figure $3 a$.

Process of feedrate scheduling, in ideal case, should find specific function for feedrate change along the programmed toolpath which will result in maintaining the representative milling force on predefined level $F_{\text {ref }}$ (Figure 3b).

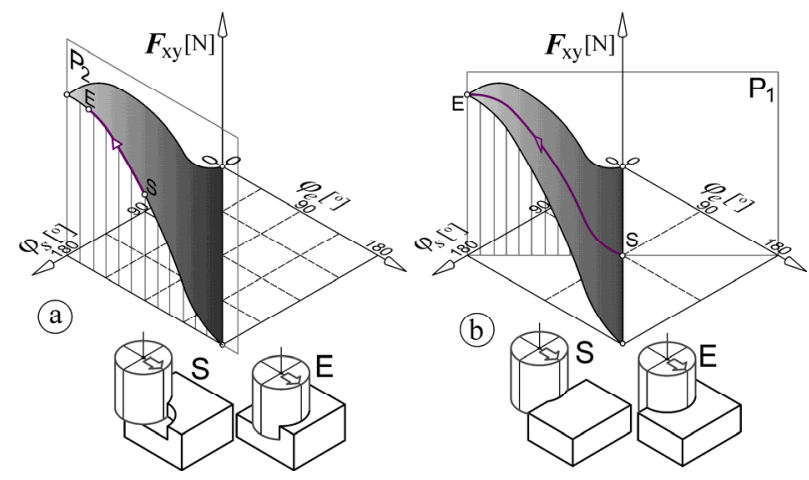

Figure 2. Changes of immersion angle along the toolpath

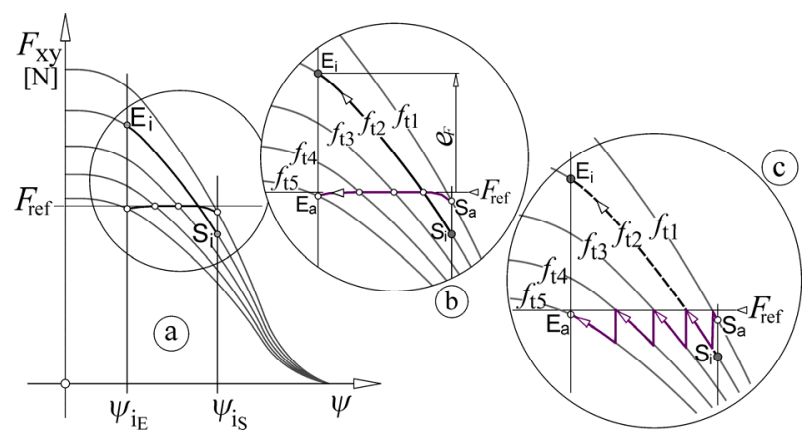

Figure 3. Maintaining the predefined force level along section of toolpath using feedrate scheduling

A more realistic approach is shown in Figure 3c. It assumes dicretization of particular toolpath element and calculation of feedrates (constants) associated with each of discretized elements, that result in desired level of representative milling force $\left(F_{\text {ref }}\right)$, with certain acceptable deviations. This process of obtaining feedrate value for a certain point (or finite length) of the toolpath is denoted as feedrate adaptation.

Term optimization of feedrate is referring to entire toolpath (pocket or contour machining). Optimization uses the results of adaptation in points of discretized toolpath, but applies some additional criteria (length of program, avoiding the intensive accelerations and frequent change in feedrates on small distances), that lead to rediscretization of toolpath and creation of final, optimized version of NC program.

\section{PREDICTION OF MILLING FORCES USING SIMULATION OF ONE SPINDLE REVOLUTION}

Generally, feedrate scheduling algorithms can be classified as MRR based or force based. For certain milling conditions (Figure 4a) they use different description of the CWE map (Figure 4b). For MMR based methods this is area $A_{\mathrm{yz}}$ (Figure $4 \mathrm{~b}$ ). Key functional block of force based feedrate scheduling procedure is module for prediction of milling forces. Model for instantaneous milling forces based on mechanistic approach with simulation of one revolution of the discretized tool [2-5] was used in this paper.

Discretization of cutting geometry of end mill identifies $i=1 \div N_{d}$ discs of finite thickness $\mathrm{d} z$ along its axis.

For particular elementary cutting edge, with length $\mathrm{d} L$, of end mill with $j=1 \div N_{f}$ flutes, three elementary cutting forces (Figure 4c) are given as functions of instantaneous uncut chip thickness $h_{\mathrm{s}}$ as:

$$
\begin{aligned}
& \mathrm{d} F_{\mathrm{t}}(i, j)=u m\left(K_{\mathrm{tc}} h_{\mathrm{s}}(i, j) \mathrm{d} z+K_{\mathrm{te}} \mathrm{d} L\right) \\
& \mathrm{d} F_{r}(i, j)=u m\left(K_{\mathrm{rc}} h_{\mathrm{s}}(i, j) \mathrm{d} z+K_{\mathrm{re}} \mathrm{d} L\right) \\
& \mathrm{d} F_{\mathrm{a}}(i, j)=u m\left(K_{\mathrm{ac}} h_{\mathrm{s}}(i, j) \mathrm{d} z+K_{\mathrm{ae}} \mathrm{d} L\right)
\end{aligned}
$$

where: $u=1$ for $\varphi(i, j) \in[0, \pi]$

$u=0$ for $\varphi(i, j) \in(\pi, 2 \pi)$

$m=1$ or $m=0$ : engagement indicator in position $\varphi(i, j), z(j)$

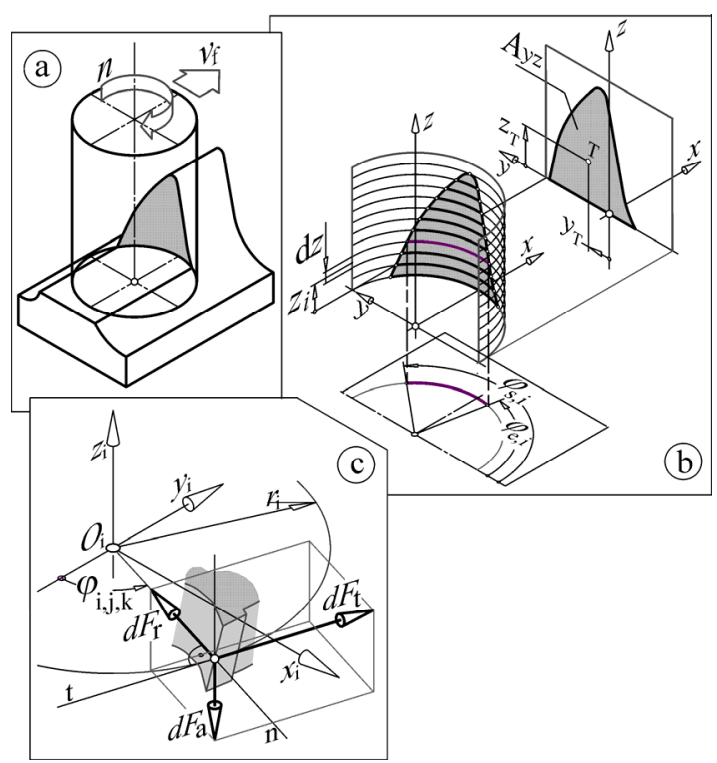

Figure 4. Basic elements for prediction of instantaneous milling forces 
Instantaneous uncut chip thickness is defined as:

$$
h_{\mathrm{c}}(i, j, k)=h_{\mathrm{c} \cdot \max }(i, j) \sin \left(\phi_{i, j, k}\right)
$$

where $k$ is referring to simulation steps (subsequent angular position of the cutter during one spindle revolution), assuming $h_{\mathrm{c}, \max }$ equal to feed per tooth, $\mathrm{ft}$.

Simple program with three concentric loops: $\mathrm{k}=$ $1 \div N_{\text {sim }}, i=1 \div N_{d}$ and $j=1 \div N_{f}$ performs calculation of instantaneous values of cutting forces (1) acting on each particular elementary edge in its angular position $\varphi=$ $\varphi_{i, j, k}$. By projecting each of them on coordinate axes of local coordinate system and summing along each axis, all instantaneous milling force components $\left(F_{\mathrm{x}}, F_{\mathrm{y}}, F_{\mathrm{z}}\right.$, $\left.F_{\mathrm{xy}}, M_{\mathrm{z}}\right)$ can be obtained for each step of the simulation $\left(k=1 \div N_{\text {sim }}\right)$.

$$
\begin{aligned}
& \mathrm{d} F_{\mathrm{x}}(i, j)=-\mathrm{d} F_{\mathrm{t}}(i, j) \cos \phi+\mathrm{d} F_{\mathrm{r}}(i, j) \sin \phi \\
& \mathrm{d} F_{\mathrm{y}}(i, j)=-\mathrm{d} F_{\mathrm{t}}(i, j) \sin \phi-\mathrm{d} F_{\mathrm{r}}(i, j) \cos \phi \\
& \mathrm{d} F_{\mathrm{z}}(i, j)=\mathrm{d} F_{\mathrm{a}}(i, j) \\
& F_{\mathrm{x}}=\sum_{i=1}^{N f} \sum_{j=1}^{N d} \mathrm{~d} F_{\mathrm{x}}(i, j), F_{\mathrm{y}}=\sum_{i=1}^{N f} \sum_{j=1}^{N d} \mathrm{~d} F_{\mathrm{x}}(i, j) \\
& F_{z}=\sum_{i=1}^{N f} \sum_{j=1}^{N d} \mathrm{~d} F_{\mathrm{a}}(i, j), F_{\mathrm{xy}}=\sqrt{F_{\mathrm{x}}^{2}+F_{\mathrm{y}}^{2}}
\end{aligned}
$$

After that it is possible to extract representative values of these components. This procedure requires following structure of input data:

- Set of values of specific cutting forces,

$$
K=\left[K_{\mathrm{tc}}, K_{\mathrm{te}}, K_{\mathrm{rc}}, K_{\mathrm{re}}, K_{\mathrm{ac}}, K_{\mathrm{ae}}\right] \text {, }
$$

- Set of the tool atributes:

$T=\left[R_{\mathrm{T}}, N_{\mathrm{f}}, \eta_{\mathrm{f}}\right],\left(R_{T}\right.$-nominal diameter,

$N_{\mathrm{f}}$-number of flutes, $\eta_{\mathrm{f}}$-helix angle of flutes),

- Set of current cutting parameters: $f_{\mathrm{t}}, \mathrm{C}=\left[\varphi_{\mathrm{s}} \varphi_{\mathrm{e}}\right]$ $\left(f_{\mathrm{t}}\right.$-feed per tooth, $\left(\varphi_{\mathrm{s}, \mathrm{i}}, \varphi_{\mathrm{e}, \mathrm{i}}\right)$ start and exit angle corresponding to each tool disc, $i$ ),

- Set of simulation parameters: $S=\left[\Delta \theta_{\text {sim }}, R_{\text {sim }}\right]$ ( $\Delta \theta_{\text {sim }}$-angular increment of spindle revolution, $R_{\text {sim }}$ - range of simulation (1 revolution or its part).

\subsection{Correction of uncut chip thickness}

Actual values of instantaneous uncut chip thickness $h_{\mathrm{c}}(i, j, k)$ in (1) are influenced by cutter runout and local curvature of toolpath, which were respected in developed program for the simulation of instantaneous cutting forces.

\section{Effect of cutter runout}

Effect of cutter runout was recognised as one of factors influencing the instantaneous chip thickness [15], [16]. Model of the end mill with its axis $(A)$ shifted from the main spindle axis $(\mathrm{O})$ is shown in Figure 5. Actual radius $\rho$ of rotating for point on tool circumference, defined with angle $\theta$ from reference point $S$, is defined as:

$$
\rho(\theta)=\rho_{\mathrm{b}} \cos \left(\theta-\theta_{\mathrm{b}}\right)+\sqrt{R_{\mathrm{T}}^{2}-\rho_{\mathrm{b}}^{2} \sin ^{2}\left(\theta-\theta_{\mathrm{b}}\right)}
$$

Two parameters of the tool runout are: $\rho_{b}$ - the maximal offset of tool axis (AK on Figure 5) from axis of rotating,

$\theta_{b}$ - angle between the reference tooth and the direction of tool axis offset.

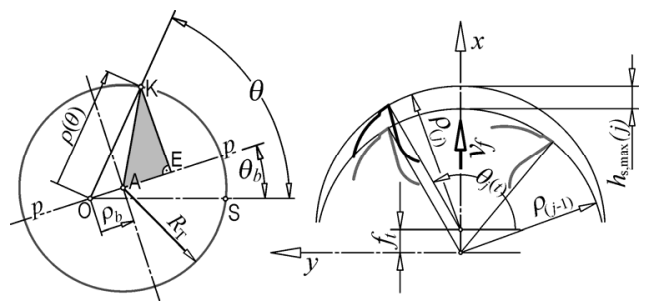

Figure 5. Actual radius of rotation for point on the tool and correction of max. uncut chip thickness

Then, maximal uncut chip thickness $h_{\mathrm{s}, \max }(\mathrm{j})$, for particular edge $j$ of the tool disc can be obtained as:

$$
\begin{aligned}
& h_{\mathrm{s}, \max }(j)=f_{t}+\rho(j)-\rho(j-1), \text { for } j=2 \div N_{\mathrm{f}} \\
& h_{\mathrm{s}, \max }(1)=f_{t}+\rho(1)-\rho\left(N_{\mathrm{f}}\right)
\end{aligned}
$$

\section{Effect of local curvature of the toolpath}

Milling along straight path (G01) assumes that all points of the tool have the same feed velocities $v_{\mathrm{f}}$. Different situation is in milling along the toolpath segments with circular interpolation (G02/G03) as shown in Figure 6. Center of the circular path is pole of velocities and only center of the tool has a programed feed velocity $v_{\mathrm{f}}$, in cases where NC program is written without tool radius compensation (G41/G42). Other points have different $v_{\mathrm{f}}$. As a consequence, (2) cannot be applied without correction. In that sense, cutting edge with angular position $\varphi$ can be treated as a part of the tool moving along straight path which has feed velocity equal to actual velocity of this point during circular interpolation. Maximum uncut chip thickness for this point is obtained from its nominal value and ratio of nominal and actual feed velocities of this point:

$$
h_{\mathrm{c}}(\phi)=K_{0203} h_{\mathrm{c}, \mathrm{n}}(\phi)=K_{0203} f_{\mathrm{t}} \sin \phi
$$

where $h_{\mathrm{c}, \mathrm{n}}$ is the nominal chip thickness which is equal to calculated feed per toth of tool center.

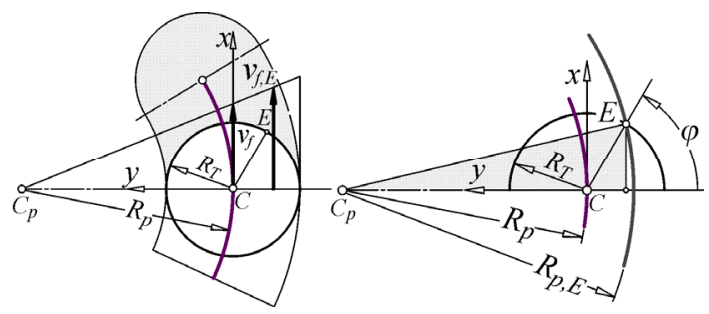

Figure 6. Actual feed velocity of point on circumference of the tool on circular segment of the toolpath

From Figure 6, corrective factor $K_{0203}$ can be obtained as:

$$
K_{0203}=\frac{R_{\mathrm{T}}(\phi)}{R_{\mathrm{p}}}=\frac{\sqrt{D_{0203}}}{R_{\mathrm{p}}}
$$

with:

$$
K_{0203}=\left\{\begin{array}{ll}
R_{\mathrm{p}}^{2}+R_{\mathrm{T}}^{2}-2 R_{\mathrm{p}} R_{\mathrm{T}} \cos \phi, & \text { for } G 02 \\
R_{\mathrm{p}}^{2}+R_{\mathrm{T}}^{2}+2 R_{\mathrm{p}} R_{\mathrm{T}} \cos \phi, & \text { for } G 03
\end{array}\right\}
$$


Correction of this type $\left(K_{0203}\right)$ is more intensive in cases with greater ratio of $R_{\mathrm{T}} / R_{\mathrm{P}}$.

Procedure defined by (1) to (4), with corrections described in this section, is proven for very accurate predictions of milling forces [14].

\section{LOCAL ADAPTATION OF THE FEEDRATE}

Force based feedrate adaptation is performed in two steps for each point of toolpath:

$$
\begin{aligned}
& v_{\mathrm{f}, \mathrm{Ad} 1}=v_{\mathrm{f}, 0} \frac{F_{\text {ref }}}{\left.F_{\mathrm{p}(0}\right)} \\
& v_{\mathrm{f}, \mathrm{Ad}}=v_{\mathrm{f}, \mathrm{Ad} 2}=v_{\mathrm{f}, \mathrm{Ad} 1}+ \\
& +\frac{\left(v_{\mathrm{f}, \mathrm{Ad} 1}-v_{f, 0}\right)\left(F_{\mathrm{ref}}-F_{p(0)}\right)}{F_{p(1)}-F_{\mathrm{p}(0)}}
\end{aligned}
$$

where $F$ refers to specific milling force component (its representative value) and $F_{\text {ref }}$ is predefined level of $F$. Feedrate $\mathrm{vf}_{0}$ is the feedrate specified in original $\mathrm{NC}$ program, in one program block or for set of subsequent blocks. Predicted value of maximal instantaneous $F$ using mechanistic force model, for simulated one revolution of end mill, for given engaged map and $v_{f, 0}$ is $F_{\mathrm{p}(0)}$. This prediction is used to calculate adapted feedrate $\left(v_{\mathrm{f}, \mathrm{Ad} 1}\right)$ in the first step. Final value for adapted feedrate $v_{\mathrm{f}, \mathrm{Ad}}$ is calculated in the second step using predicted value of $F_{\mathrm{p}(1)}$ force for feedrate $v_{\mathrm{f}, \mathrm{Adl}}$, calculated in previous step and with consideration of predefined limits for feed per tooth.

Such simple procedure, on the other hand, is not easy for implementation. A major difficulty is the need for reconstuction of CWE map in points of the toolpath, according to the original version of NC part programm and to the chosen increment of path length. This map is required for application of mechanistic model of milling forces based on simulation of one spindle revolution of discretized cutter geometry. From this reason several functional blocks, for processing original $\mathrm{NC}$ code and workpiece model were developed. These functions are described in sections 4.1 and 4.2. In general case, specific cutting forces are unknown, and they need to be obtained through experiments. One example of experimental identification of these forces is described in section 4.3 .

\subsection{Interpretation of NC- part program and discre- tization of the toolpath}

Specific Matlab function (nc_explorer.m) is developed for processing the NC-part program in order to extract toolpaths in planes $z=$ const, and for their discretization according to chosen increment value. Modal action of functions in G-code of the part program makes some difficulties in exact recognition of particular elements of the toolpath $(\mathrm{G} 01, \mathrm{G} 02, \mathrm{G} 03)$. Thus, specific format for interpretation of the toolpath segments was applied. Function $n c$ explorer.m performs scanning of original $\mathrm{NC}$-code and completion the set (frame) of attributes for each block with feed motion. In this way, each block of the toolpath has the same data structure. One example is shown on Figure 7. Each G02 and G03 is decomposed on its quadrants.

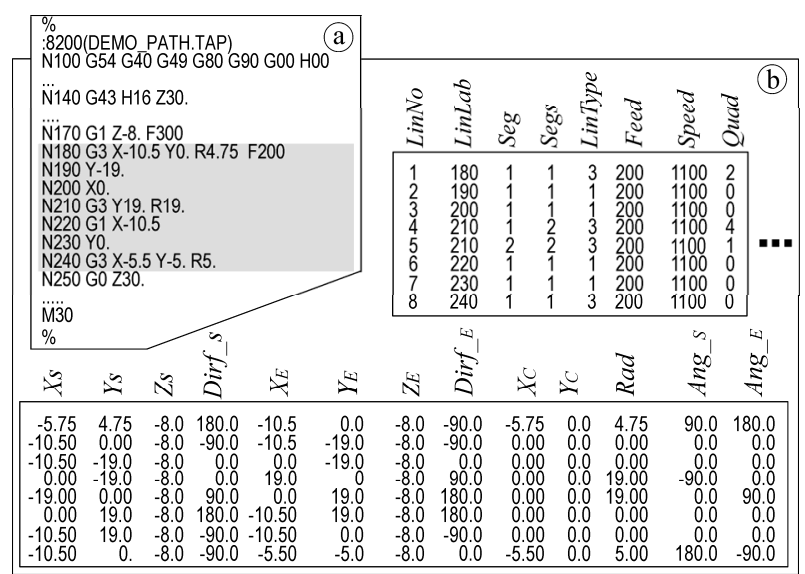

Figure 7. An example of NC code (a) and frames of elements of the toolpath (b)

One frame includes: frame number, label of block in original NC program (LineLab), number of quadrants (Segs) of decomposed arc, path-type (LinType) for G01, G02, G03, programmed feed (Feed) and spindle speed (Speed) and quadrant of arc (Quad).

The other attributes are shown in lower part of Figure 7: start and end position, direction of feed vector in these points (Dirf_s, Dirf_e). Attributes for arc are: position of the centre, radius, and central angles of start and end point (Ang_s, Ang_e ). Such data structure enables easier further processing of the toolpath.

Function $n c$ explorer. $m$ performs disretization of the toolpath and creates matrix with description of discretized path with elements with same data structure as shown on Figure $7 b$.

\subsection{The model of the workpiece and routines for its processing}

Force based feedrate scheduling requires approximation of workpiece volume in appropriate form. Workpiece model should be suitable for extraction of CWE map in analytical form.

\section{Z-map of the workpiece}

Well known Z-map presentation [17], [18], has a simple data structure in form of matrix that defines top point coordinates of linear elements parallel to $z$ axis (Figure 8a). Such elements starts fom grid in chosen base $z$ plane with constant increments $\Delta x y$ in both directions $x$ and $y$. Each element is limited by the hull of workpiece.

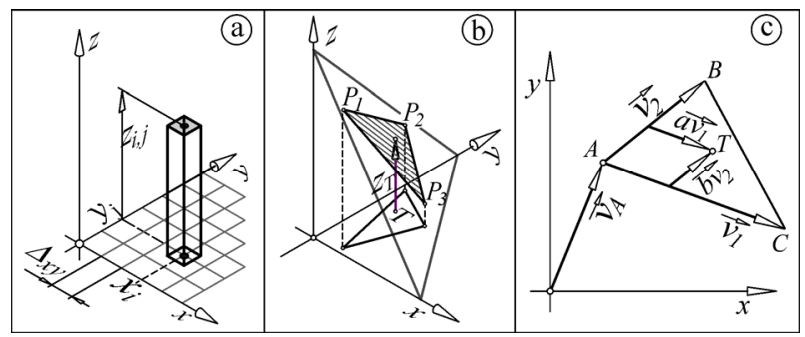

Figure 8. Element of the Z-map (a), its identification by the patch of the hull, condition for point inside triangle (c)

Analytically creating the Z-map can be difficult. In order to use power of CAD systems a specific Matlab function was developed. It uses ASCII STL output of solid model, created in $\mathrm{CAD}$, and converts it to the $\mathrm{Z}$ - 
map (calculates z-coordinates of the hull for given incement of base grid). Each point of the base $\left(x_{i}, y_{j}\right)$ should be checked if it belongs to the projection of the certain patch of the STL file (Figure 8b) .

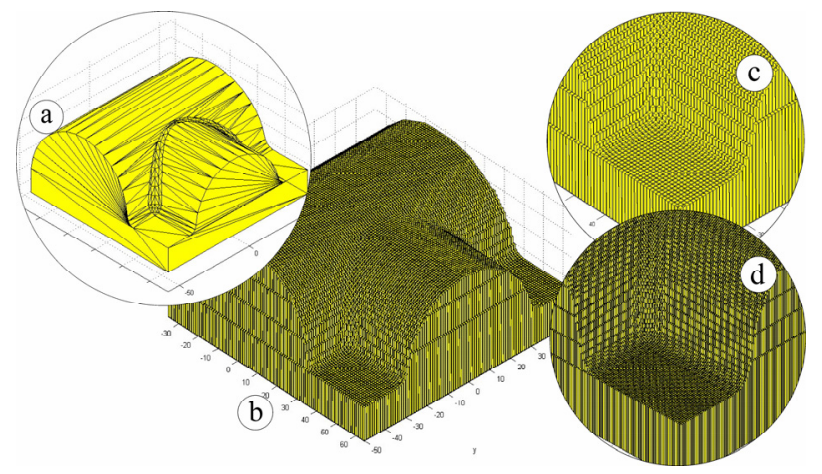

Figure 9. An example of creating the Z-map model

After that, distance $\left(z_{i j}\right)$ along z-direction between point in the base and intersection with identified patch should be calculated (Figure 8c). Figure 9 shows one example of this procedure: STL model interpreted with patches (a), Z-map model (b), and two examples (c,d) created with different chosen reasolution of the Z-map base.

\section{Simulation of material removal}

Automatization of the procedure for prediction of milling forces along the described toolpath requires functions for updating the workpiece volume, according to progression of the NC part program. Such functions are not aimed for visualisation of the material removal. Their goal is to update workpiece model in analythic form as necessary condition for correct reconstruction of CWE map in all points of the toolpath. This goal is achieved by two specific Matlab functions which should be applied for arbitrary current element of the toolpath (Figure 10). They use specification of the frames of the discretized toolpath (Figure 7).

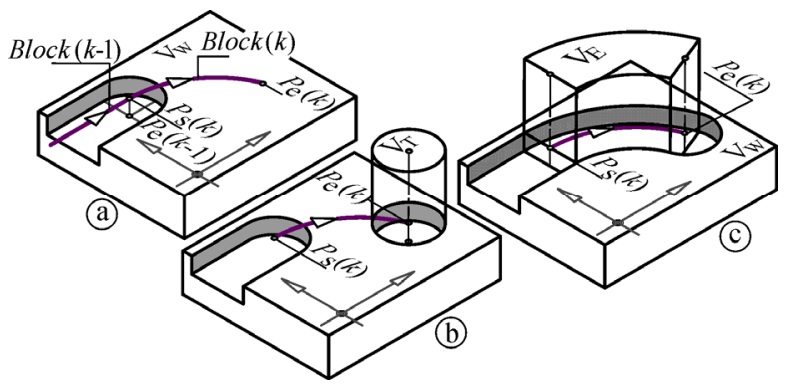

Figure 10. Functions for updating the Z-map model: plunger (b) and digger (c)

First of them (plunger.m) cuts off elements of the Zmap in end position of the path segment, according to profile of the tool. The second one (digger.m) modifies elements of Z-map according to the tool profile and description (frame) of current segment of the path. This modification means creating of tool envelope on discrete length of its path and its substraction of workpiece volume.

\section{Extraction CWE map}

A figure which presents the area of engagement of cutting tool into workpiece material here is denoted as an CWE map. In certain point of discretized toolpath this reconstruction assumes identification of the elements of the workpiece Z-map distributed along half-cylinder defined with current coordinates of the tool tip and cutter diameter and oriented according to the instantaneous vector of the feed speed (Figure 11).

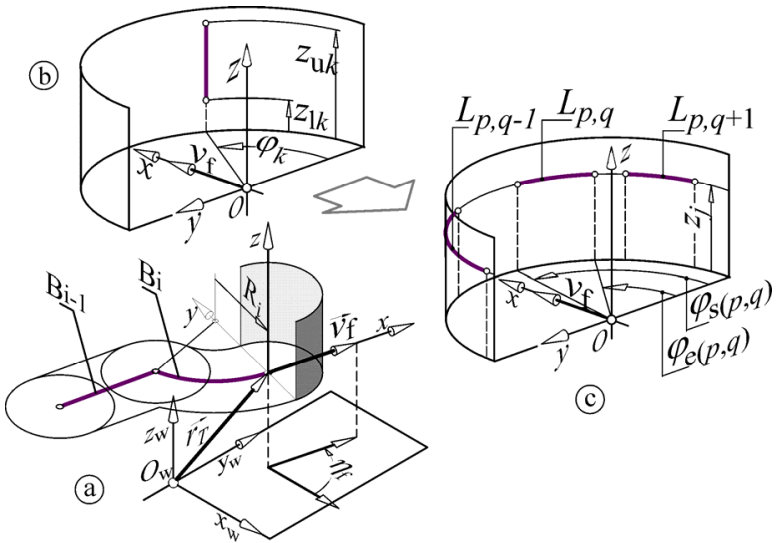

Figure 11. Identification of the CWE map: Problem formulation (a), Data structures: $z(\varphi)(b)$ and $\varphi(z)(c)$

Two appropriate Matlab functions are developed. First of them ( $m a p \_$phiz.m) performs the analysis of sub -matrix of the Z-map corresponding to square $\left(D_{\mathrm{t}} \times D_{\mathrm{t}}\right)$ in its base with center in current point of discretized toolpath. It finds lenght and local angular position of elements of Z-map on half cylinder defined by actual direction of feed velocity vector (Figure 11a). This function creates CWE map in form $z(\varphi)$ shown on Figure 11b.

More suitable form of this map is its presentation as arcs on half cylinder on equidistant z-planes corresponding to thickness of the discs of the discretized tool (Figure 11c).

Another Matlab function (phiz2zphi.m) was developed for this purpose. In order to manipulate with more complex CWE maps it creates a matrix in following form, allowing up to two $\operatorname{arcs}(A, B)$ of each z-level of this map:

$$
M_{\phi, z}=\left[\begin{array}{ccccc}
z_{1} & \phi_{\mathrm{sA}, 1} & \phi_{\mathrm{eA}, 1} & \phi_{\mathrm{sB}, 1} & \phi_{\mathrm{eB}, 1} \\
z_{1} & \phi_{\mathrm{sA}, 2} & \phi_{\mathrm{eA}, 2} & \phi_{\mathrm{sB}, 2} & \phi_{\mathrm{eB}, 2} \\
\cdots & & & & \\
z_{\mathrm{m}} & \phi_{\mathrm{sA}, \mathrm{m}} & \phi_{\mathrm{eA}, \mathrm{m}} & \phi_{\mathrm{sB}, \mathrm{m}} & \phi_{\mathrm{eB}, \mathrm{m}}
\end{array}\right]
$$

\subsection{Specific cutting forces}

Experiments needed for procedure of identification of specific cutting forces were performed using machine (horizontal machining center HMC500/40, Lola Corp.) and installation shown in Figure 12. In this paper the analysis is reduced to the components Fx and Fy.

Workpiece was fixed on platform of 4-component strain gauge dynamometer (S1) on V-block, on machine table. One inductive proximity switch (S2) with battery module (K2) uses target on spindle face enabling trigger signal marking start of each full revolution of the spindle. Signals of Fx and Fy, amplified with laboratory amplifiers (K1) and trigger signal were connected as voltage inputs on appropriate module (M1) of the DAQ system (B2) and computer with DAQ software. 


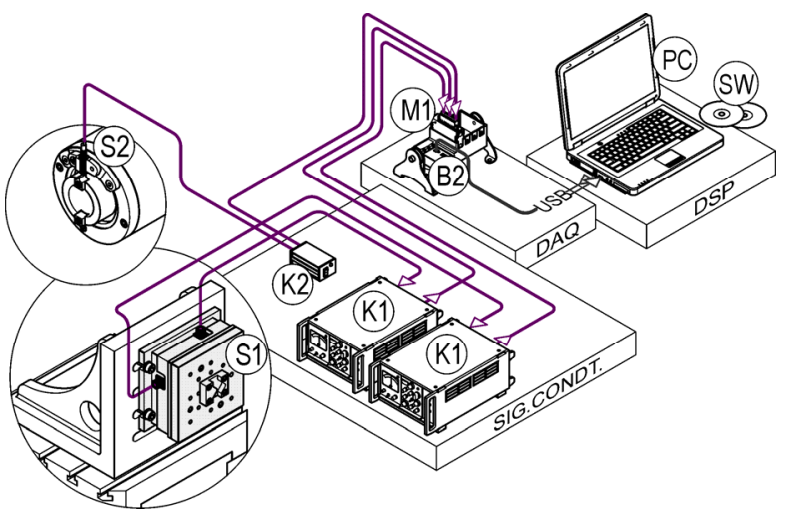

Figure 12. Experimental installation for identification of specific cutting forces

Milling conditions were chosen in specific way. In sufficiently rigid plate, one slot was previously made on its bottom side. In each experiment, first step is milling of small open pocket slightly wider than tool diameter leaving thin lamella with small overhang from base material. Second step is milling of lamella with particular feed per tooth $f_{\mathrm{t}}$, with maeasuring of two force components. For each $f_{\mathrm{t}}$ these two steps were repeated.

Such setup of experiments was made in order to ensure milling of small axial depth of cut with minimal risks of pulling of thin material by helical cutting edges of the tool.

Typical time series for measured $F_{\mathrm{x}}$ and $F_{\mathrm{y}}$ in experiments are shown in Figure 13. Their representative sections (section $\mathrm{C}$ on figure) are subject of further analysis. Part of these sections between round number of trigger signal were used for calculating mean values of force components $F_{\mathrm{x}}$ and $F_{\mathrm{y}}$.

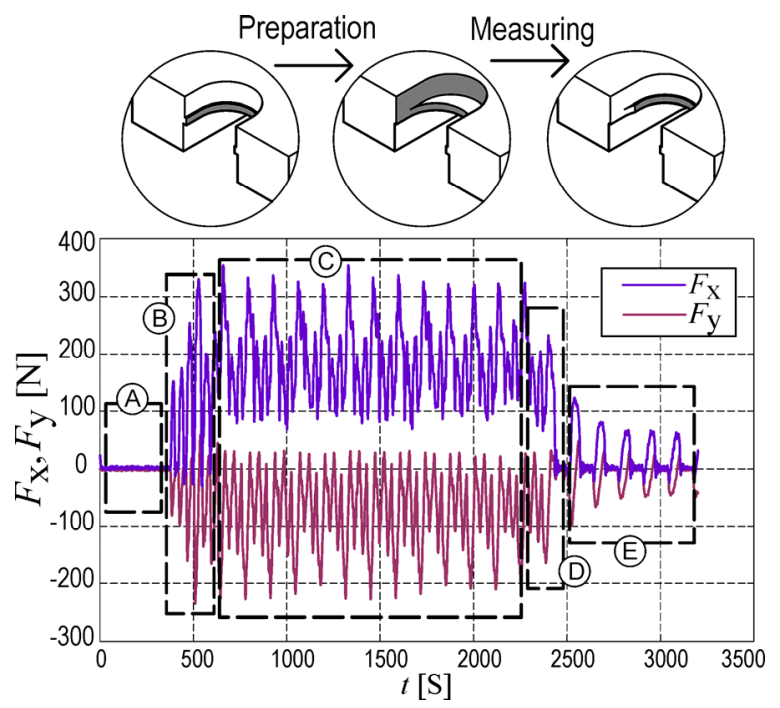

Figure 13. Preparation and milling of specimen (a), Typical time series in experiments with milling (b)

Material, used in experiments was AlZn4Mg2 (ENAW 7019). Flat end mill $\varnothing 16$ HSSE, with 3 flutes, $10^{\circ}$ rake angle, and $30^{\circ}$ helix angle. Thickness of lamella was $a=2 \mathrm{~mm}$. Applied values of feed per tooth were: $f_{\mathrm{t}}=0.015$; $0.03 ; 0.05 ; 0.07 ; 0.09 ; 0.11 ; 0.13 \mathrm{~mm} / \mathrm{t}$.

Mean values of $F \mathrm{x}$ and $F \mathrm{y}$ calculated from time series for each of 7 experiments are shown in Figure 14 as a function of $f_{\mathrm{t}}$. Using Matlab function polyfit, estimation of the slope and intercept of linear approximation of functions $\bar{F}_{\mathrm{x}}\left(f_{\mathrm{t}}\right)$ and $\bar{F}_{\mathrm{y}}\left(f_{\mathrm{t}}\right)$ was made.

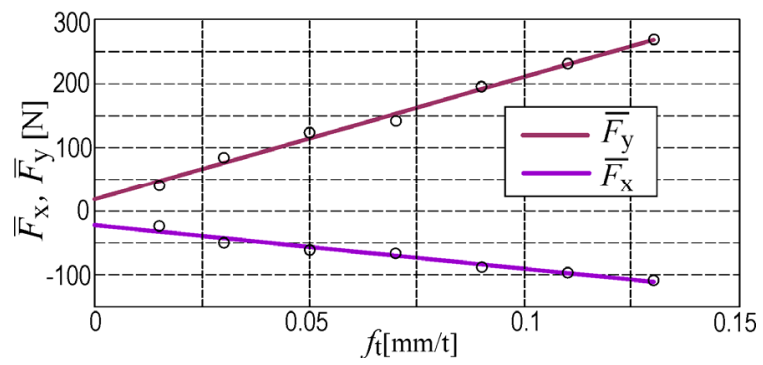

Figure 14. Mean values of $F_{\mathrm{x}}$ and $F_{\mathrm{y}}$ obtained from experiments

Based on well known procedure [11], specific cutting forces were calculated as:

$$
\begin{aligned}
& K_{\mathrm{tc}}=1113.1 \mathrm{~N} / \mathrm{mm}^{2}, K_{\mathrm{rc}}=384.2 \mathrm{~N} / \mathrm{mm}^{2} \\
& K_{\mathrm{te}}=11.1 \mathrm{~N} / \mathrm{mm}, K_{\mathrm{re}}=11.6 \mathrm{~N} / \mathrm{mm} .
\end{aligned}
$$

These values are used in one example of application the presented procedure for feedrate optimization in Section 6. Also the sam material and the same tool geometry are used in experimental verification in Section 7.

\section{OPTIMIZATION OF THE FEEDRATE ALONG THE TOOLPATH}

Procedure of optimization of the feedrate starts from discretized toolpath with coordinates of subsequent points and their links to the blocks of original NC code and associated feedrates obtained through procedure of adaptation of feedrate according to the given level of the chosen force component. In this phase some corrections of calculated feedrates are made:

Q1. Filtering the calculated values of feedrate obtained during its adaptation in discrete points. This filtering can be expressed as:

$$
\begin{aligned}
& v_{\mathrm{f}, \mathrm{Ad} 2}(k)>v_{\mathrm{f}, \mathrm{Ad} 2}(k-1) \wedge \\
& \wedge v_{\mathrm{f}, \mathrm{Ad} 2}(k)>v_{\mathrm{f}, \mathrm{Ad} 2}(k+1) \Rightarrow \\
& \Rightarrow v_{\mathrm{f}, \mathrm{Ad} 2}(k)=0.5\left(v_{\mathrm{f}, \mathrm{Ad} 2}(k-1)+v_{\mathrm{f}, \mathrm{Ad} 2}(k+1)\right)
\end{aligned}
$$

Such criterion prevents the sudden changes of feed velocities in short segments of the toolpath. It has restrictive action and leads to the drop of the MRR and it will result in level of chosen representative force lower than specified, but contributes to the better surface roughness and prevents faster wear of the milling tool.

Q2. After applying of Q1, specific routine performs compression of discrete elements of the toolpath in longer segments. Calculated feedrates during adaptation are subject of rounding to values of given discrete scale of feedrates. Compression, in this case, means identification of longer path segment which is a substitution for the set of subsequent parts of initially (uniformly) discretized toolpath.

Q3. During this step the additional rediscretization of the toolpath is performed in order to prevent high accelerations or decelerations between segments of the toolpath created in steps Q1 and Q2.

The procedure which performs modification of the calculated feedrates through steps $\mathrm{Q} 1 \div \mathrm{Q} 3$ can be repeated several times in order to achieve smoother distribition of the feedrate along the toolpath. 


\section{ONE EXAMPLE OF OPTIMIZATION OF THE FE- EDRATE ALONG PROGRAMMED TOOLPATH}

Prepared blank for machining test, and premachined internal contour are shown on Figure 15. Chosen geometry of this part was made in order to ensure intensive changes of engaging map during milling according to the NC program in test. Maintaining the desired level of resulting force in $x y$ plane was chosen as optimization criterion in this experiment.

Toolpath and appropriate NC part program are shown in Figure 15c,d, for this experiment [22]. Shaded lines of NC program are subject of feedrate optimization according to given criterion $\left(F_{\mathrm{xy}, \max }\right)$.

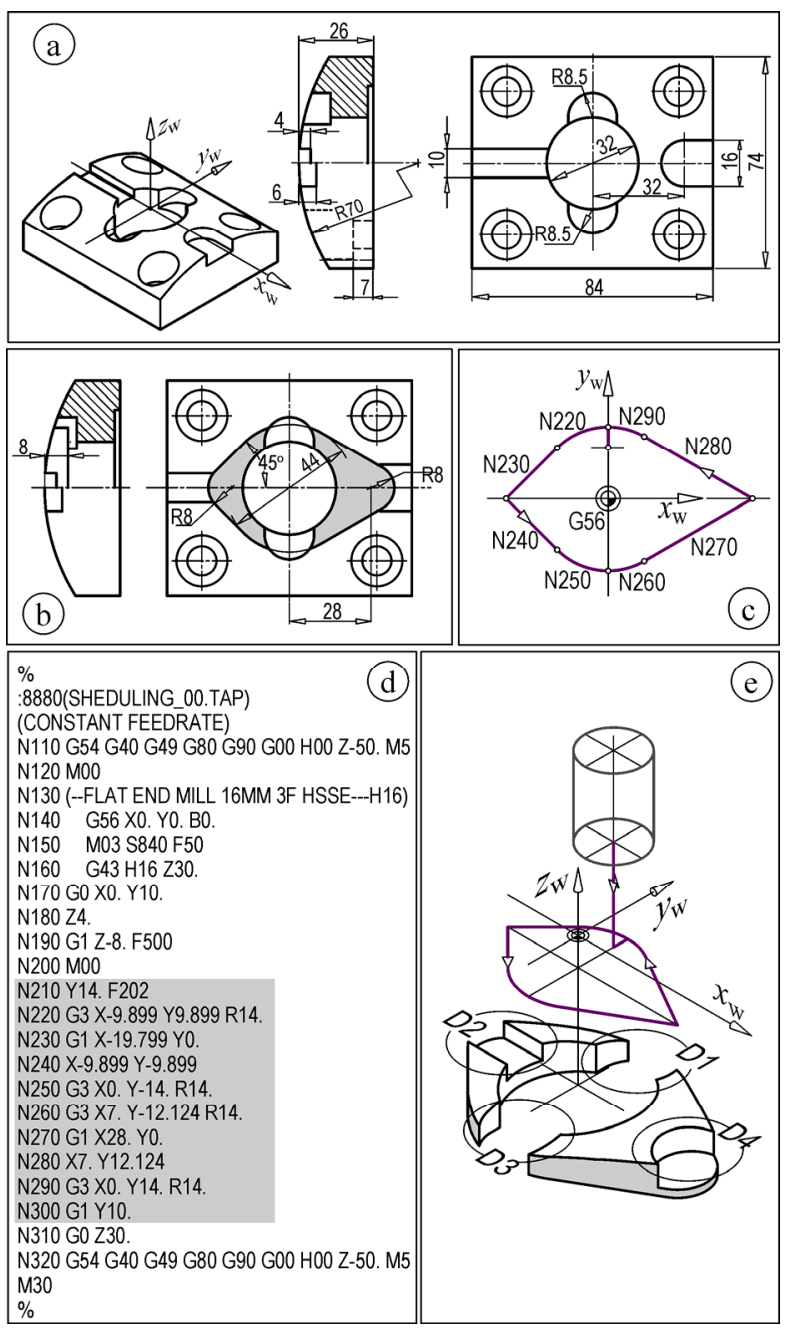

Figure 15. Contour milling in experiment: raw piece (a), finished part (b), toolpath (c), part program (d) and volume intended to remove (e)

This version of NC program is designated as original one and it was programmed with constant feedrate. Variation of axial depth of cut is between 0 and $8 \mathrm{~mm}$ and radial depth of cut varies between 0 and $16 \mathrm{~mm}$. Whole toolpath was programmed with constant feed per tooth $(0.08 \mathrm{~mm} / \mathrm{t})$. Workpiece material was EN AW7019, the same as was used in experiments for identification of specific cutting forces.

\subsection{Feedrate adaptation in points of disretized toolpath}

Discretization of the toolpath and reconstruction of engaged map in points of toolpath were performed using functions described in section 4.2. Simulation of instantaneous values of $F_{\mathrm{xy}}$ force is performed according to the procedure described in Section 3. Z-map model of prepared blank for this example is shown on Figure 16.

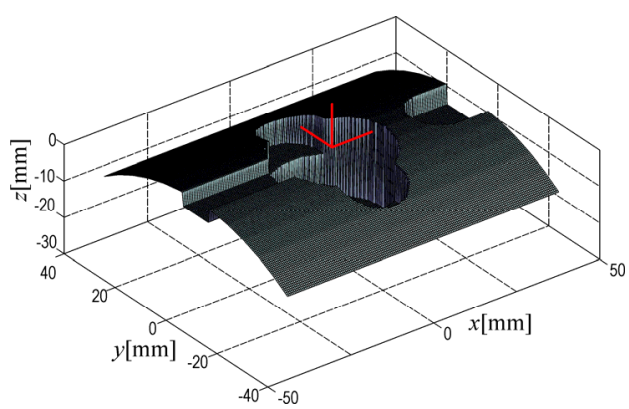

Figure 16. Prepared Z-map of the raw piece for example of application of procedure

Specific limits for calculated feed per tooth were set in this case in order to prevent tool damage. Parameters for feedrate adaptation procedure are shown in Table 1 .

Results of adaptation procedure are given in Figure 17.

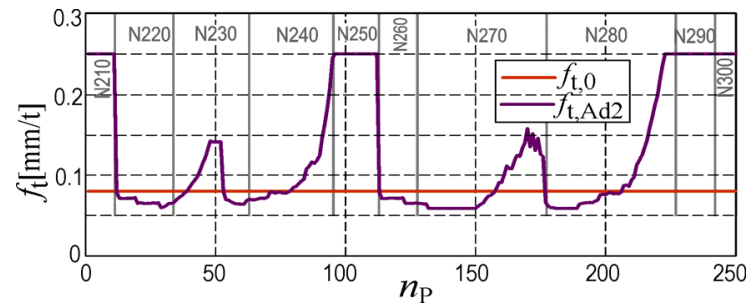

Figure 17 Feedrates per tooth in original NC program and after adaptation

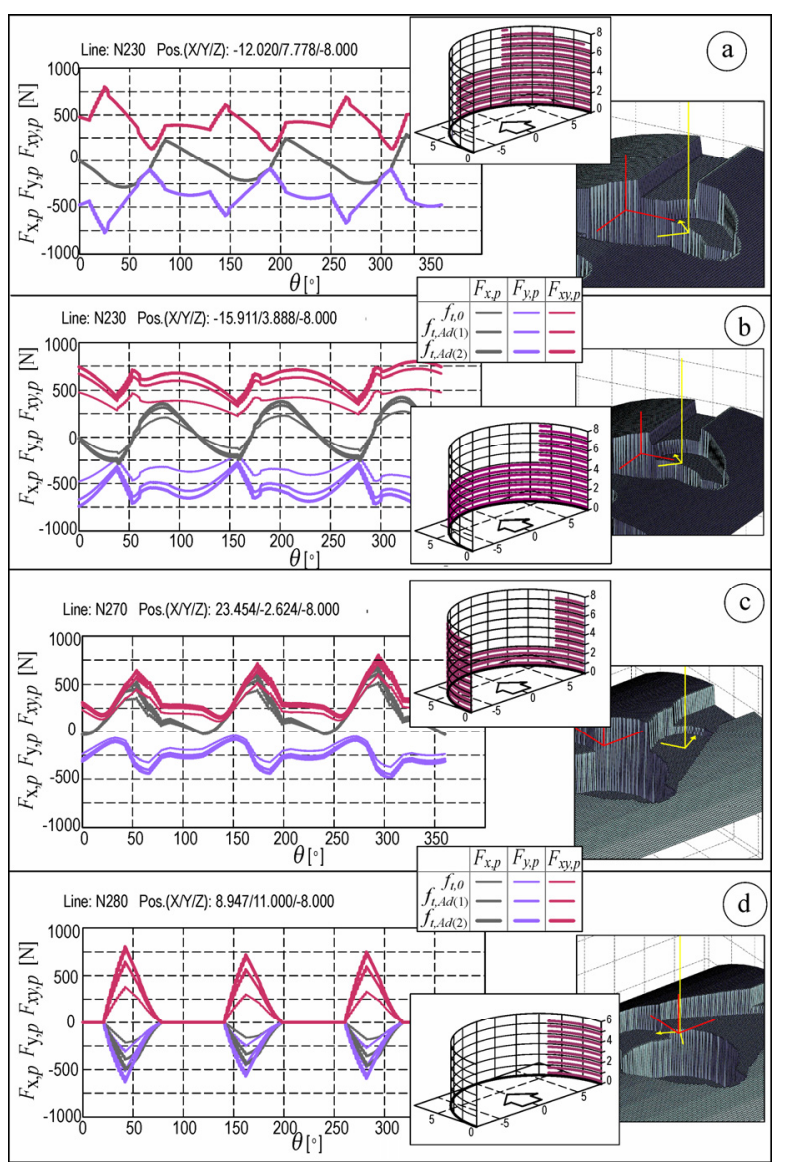

Figure 18. Four examples of prediction of instantaneous values of milling forces in points of the toolpath during adaptation procedure 
For this purpose, Matlab program for feedrate adaptation procedure (feed_adapt.m) was enhanced with visualization in each point of the discretized toolpath. Results for particular 4 points are shown in Figure 18. Results for each point assume: actual workpiece shape (updated Zmap), actual NC block, position of the tool tip, orientation of feedrate vector and reconstruction of CWE map. Corresponding graph for each point shows results of instantaneous values of $F_{\mathrm{x}}, F_{\mathrm{y}}$ and $F_{\mathrm{xy}}$, for feedrate given in original NC program, as well as for feedrate obtained in both steps of adaptation procedure (10),(11).

Table 1. Parameters used in example for optimization of feedrate

\begin{tabular}{|c|c|}
\hline Increment for toolpath disretization, $\Delta L_{p}[\mathrm{~mm}]$ & 0.5 \\
\hline Increment of grid of $Z$-map, $\Delta m[\mathrm{~mm}]$ & 0.5 \\
\hline Thickness of cutter discs, $h_{d}[\mathrm{~mm}]$ & 0.5 \\
\hline Angular incr. of simul. 1 spindle rev. $\Delta \theta\left[^{\circ}\right]$ & 1.0 \\
\hline Reference value for milling force, $F_{\text {ref }}[\mathrm{N}]$ & 800 \\
\hline Limits for feed per tooth, $f_{\mathrm{t}, \min }-f_{\mathrm{t}, \max }[\mathrm{mm} / \mathrm{t}]$ & $0.03-0.25$ \\
\hline
\end{tabular}

Effects of feedrate adaptation procedure are summarized in Figure 19. It shows predicted maximal $F_{\mathrm{xy}}$ values in points along discretized toolpath for feedrate given in original NC program, as well as for feedrate obtained through its adaptation.

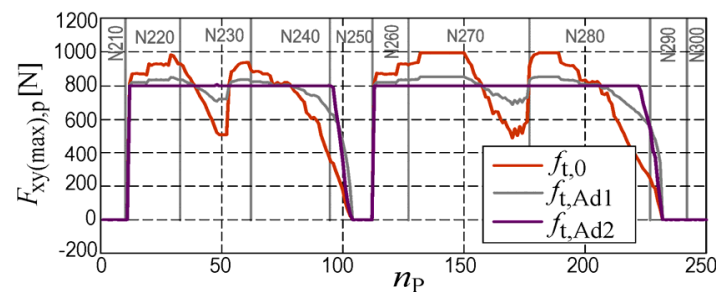

Figure 19. Predicted values of $F_{\mathrm{xy}}$ along toolpath after feedrate adaptation

\subsection{Feedrate optimization along the toolpath}

Values of adapted feedrate associated to 250 points of discretized toolpath are subject of corrections according to criteria Q1-Q3 (Section 5). Modified values obtained with Q1 are denoted as $v_{\mathrm{f}, \mathrm{Ad} 3}$. According to rule Q2 these values are rounded to nearest lower value of previously defined discrete scale of feedrates. In this example scale with increment of $30 \mathrm{~mm} / \mathrm{min}$, starting from zero was chosen. In this way set of $v_{\mathrm{f}, \mathrm{Ad} 3}$ was transformed in new one, denoted as $v_{\mathrm{f}, \mathrm{Ad} 4}$. Both sets of recalculated feedrates along the toolpath are shown on Figure 20. Distribution of $v_{\mathrm{f}, \mathrm{Ad} 4}$ does not activate criterion Q3 for elimination of high accelerations, because limiting step change between two subsequent points was set on $300 \mathrm{~mm} / \mathrm{min}$.

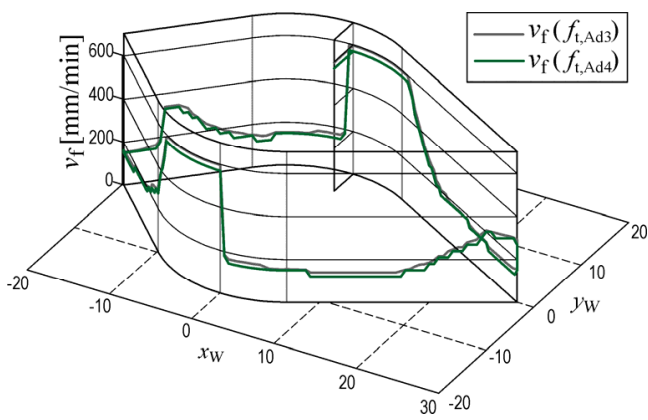

Figure 20. Distribution of feedrate along toolpath after optimization
Specific Matlab function ( $t p \_$rediscretizer.m) creates new description of the toolpath with associated feedrates. This function uses values of $v_{\mathrm{f}, \mathrm{Ad} 4}$ and attribute frames of initially discretized path in form as shown on Figure 7. NC program, after optimization according to criterion $\max \left(F_{\mathrm{xy}}\right)=800 \mathrm{~N}$ is shown on Figure 21 .

Rediscretization, performed in this step, results in reduction of number of points on toolpath: from 250 points (feedrate adaptation) to 56 points in optimized NCpart program.

\begin{tabular}{|l|l|}
\hline$\%$ & N44G3X0.Y-14.000R14.F570 \\
:8022(S802SHED.TAP) & N45G3X0.500Y-13.991R14.F180 \\
(SHEDULINGFXY800N) & N46G3X7.000Y-12.124R14.F150 \\
(RESHED.VFINCR=30MM/MIN) & N47G1X8.7321Y-11.124F150 \\
N10G54G40G49G80G90 & N48G1X17.392Y-6.124F120 \\
N11G0H00Z-50.M5 & N49G1X19.558Y-4.874F150 \\
N12M00 & N50G1X20.424Y-4.374F180 \\
N13(-MILL16MM3FHSSE---H16) & N51G1X21.723Y-3.624F210 \\
N14G56X0.Y0.B0. & N52G1X23.022Y-2.874F240 \\
N15M03S796F191 & N53G1X24.321Y-2.124F270 \\
N16G43H16Z30. & N54G1X24.754Y-1.874F300 \\
N17G0X0.Y10. & N55G1X25.620Y-1.374F330 \\
N18G1Z-8.F200 & N56G1X27.676Y-0.187F300 \\
N19M00 & N57G1X28.000Y0.F270 \\
N20G1X0.Y14.000F570 & N58G1X22.804Y3.000F120 \\
N21G3X-0.500Y13.991R14.F360 & N59G1X19.340Y5.000F150 \\
N22G3X-0.999Y13.9643R14.F180 & N60G1X14.143Y8.000F180 \\
N23G3X-7.987Y11.4979R14.F150 & N61G1X13.277Y8.500F210 \\
N24G3X-9.543Y10.2436R14.F120 & N62G1X12.844Y8.750F240 \\
N25G3X-9.899Y9.8990R14.F150 & N63G1X11.978Y9.250F270 \\
N26G1X-11.313Y8.485F150 & N64G1X11.545Y9.500F300 \\
N27G1X-12.374Y7.424F180 & N65G1X11.112Y9.750F330 \\
N28G1X-13.435Y6.364F210 & N66G1X10.679Y10.000F360 \\
N29G1X-13.788Y6.010F240 & N67G1X10.246Y10.250F390 \\
N30G1X-14.495Y5.303F270 & N68G1X9.813Y10.500F420 \\
N31G1X-15.203Y4.596F300 & N69G1X9.380Y10.750F450 \\
N32G1X-16.617Y3.182F330 & N70G1X8.947Y11.000F510 \\
N33G1X-16.970Y2.828F180 & N71G1X8.514Y11.250F540 \\
N34G1X-19.799Y0.F150 & N72G1X7.000Y12.124F570 \\
N35G1X-16.970Y-2.828F150 & N73G3X0.Y14.000R14.F570 \\
N36G1X-13.081Y-6.717F180 & N74G1X0.Y10.000F570 \\
N37G1X-12.020Y-7.778F210 & N75G0Z30. \\
N38G1X-10.960Y-8.838F240 & N76(---ENDOFPR0G---) \\
N39G1X-9.899Y-9.899F270 & N77G54G40G49G80G90 \\
N40G3X-9.540Y-10.247R14.F330 & N78G0H00Z-50.M5 \\
N41G3X-9.168Y-10.581R14.F390 & M30 \\
N42G3X-8.784Y-10.901R14.F420 & $\%$ \\
N43G3X-8.389Y-11.208R14.F480 & \\
\hline
\end{tabular}

Figure 21. Modified NC part program after optimization

\section{EXPERIMENTAL VERIFICATION}

The procedure, applied for optimization of the feedrate along toolpath for milling operations in plane $\mathrm{z}=$ const, described in previous section, was examined through experiment [22]. Machining test was performed according to the NC part program from Figure 21. Experimental setup is similar as the one shown on Figure 12. Its enhanced variant provides simultaneous acquisition of two components $F_{x, w}(t)$ and $F_{y, w}(t)$ of milling force as well as actual positions (workpiece coordinates) of two servo axis of the machine: $x_{w}(t)$ and $y_{w}(t)$, obtained from two half-bridge inductive displacement sensors $( \pm 50$ $\mathrm{mm})$ with its amplifiers.

Figure 22 shows time series of milling force component $F_{x, w}(t)$ and $F_{y, w}(t)$, during machining in performed test and also changes of position of machine axes $\left(x_{w}, y_{w}\right)$ in workpiece coordinate system. Two position signals enable reconstruction of the toolpath.

One specificity of the performed experiment is presence of chatter vibrations in certain parts of the toolpath. This is clearly visible in time series of $F \mathrm{x}$ and $F \mathrm{y}$. Chatter zones in these time series are marked with W1 
and W2 on Figure 22. Presence of chattering is visible in cetrain zones of machined part in form of rough marks (Figure 23). Mechanism of chatter evolving (transition from stable to unstable machining) is clearly visible in zones marked as V1 nd V2 in time series of milling force components. One of them (V1 of $F \mathrm{X})$ is shown on Figure 24.
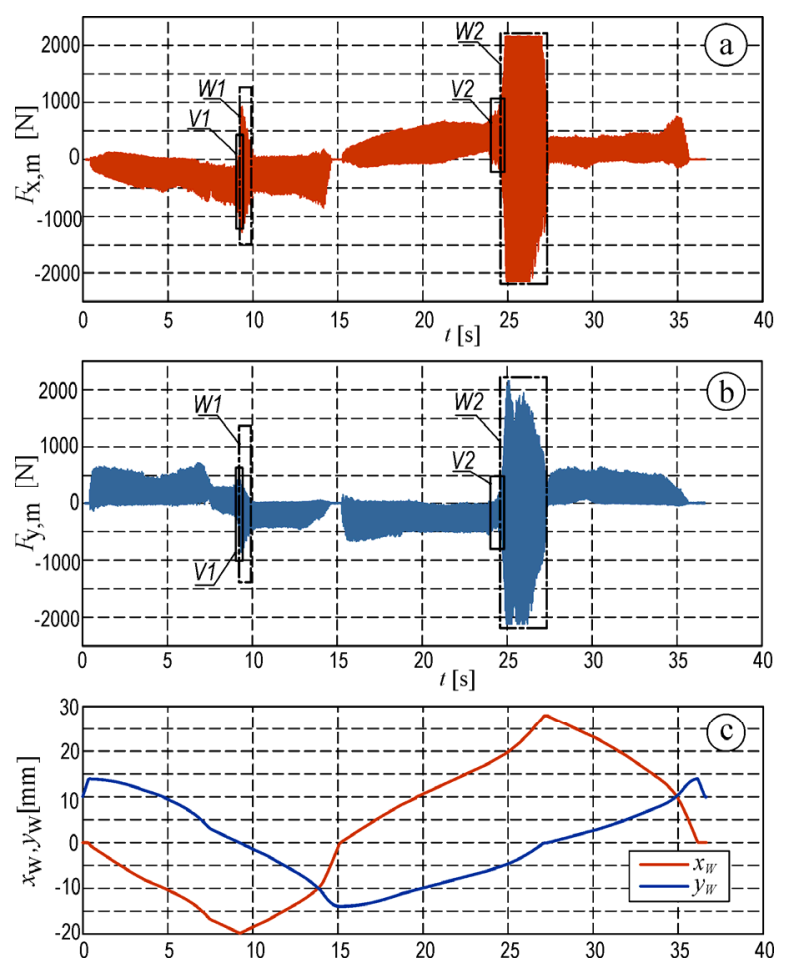

Figure 22. Time series of two milling force components (a, b) and coordinates of the tool tip(c)

In its early part, tooth entering frequency $\left(f_{\mathrm{t}}=39.8 \mathrm{~Hz}\right)$ is dominant. Structural dynamics is visible as higher frequency component $\left(f_{\mathrm{C}} \approx 280 \mathrm{~Hz}\right)$ with small amplitude in this phase. During period of approximately $0.25 \mathrm{~s}$ amplitude of this component grows rapidly and becomes dominant.
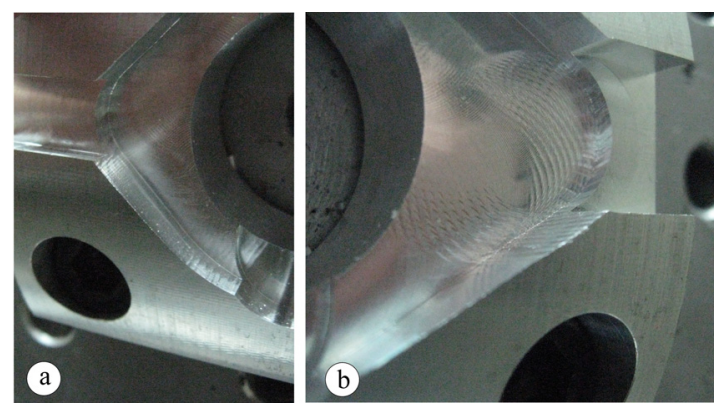

Figure 23. Details of machined surface generated in presence of chatter vibrations

Amplitude of vibrations, in unstable milling conditions, are not visible in time series of $F_{\mathrm{x}}$ and $F_{\mathrm{y}}$, due to the limited output $( \pm 10 \mathrm{~V})$ of applied amplifiers. Regarding conditions of experiment chatter frequency can be adressed to natural frequency of used 4-component dynamometer with strain gauges, as substructure with lowest stiffness.

Simultaneous acquisition of servo axis positions and milling force components allows creating graph of instantaneous force components or its representative values along the toolpath. In case of analysis of representative values of force components specific processing of time series needs to be performed.

Evaluation of applied procedures for feedrate optimization includes comparing the representative values of $F_{\mathrm{xy}}$ milling force component (its maximum) obtained through experiment with its chosen level $(800 \mathrm{~N})$.

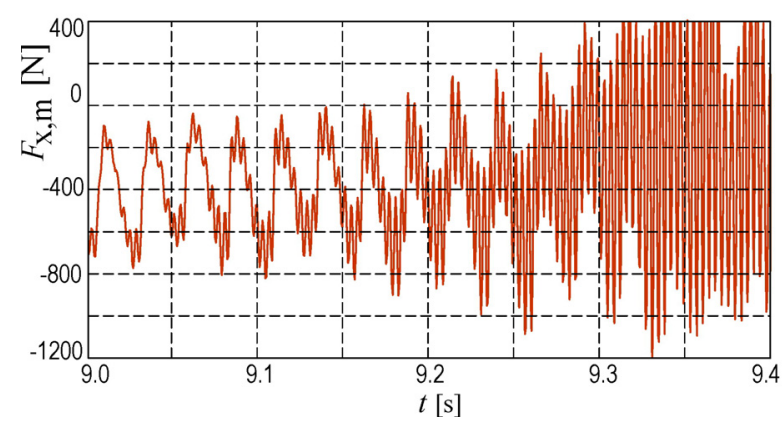

Figure 24. One example of evolving the chatter vibrations

Instantaneous component forces $F_{\mathrm{x}, \mathrm{m}}$ and $F_{\mathrm{y}, \mathrm{m}}$ were measured during experiment. Its vector sum in sample $k$ is independent of current direction of feed velocity vector:

$$
F_{\mathrm{xy}, \mathrm{m}}(k)=\sqrt{F_{\mathrm{x}, \mathrm{m}}^{2}(k)+F_{\mathrm{y}, \mathrm{m}}^{2}(k)}
$$

Obtained time series of measured instantaneous values of $F_{\mathrm{xy}, \mathrm{m}}(t)$ is shown on Figure 25.

First step of this procedure asumes extraction of $x$ nd $y$ axis positions $x_{\mathrm{w}}(K), y_{\mathrm{w}}(K)$ in corresponding samples $K\left(K=1 \div 1+q \cdot N_{\mathrm{sp}}, q=1,2,3 ..\right)$, from time series $x_{\mathrm{w}}(k)$ and $y_{\mathrm{w}}(k)$ recorded with sampling frequency $f_{\mathrm{s}}$.

By spindle speed $n_{\mathrm{sp}}$, integer $N_{\mathrm{sp}}$ is equal to number of samples during one full spindle revolution:

$$
N_{\text {sp }}=\text { floor }\left(\frac{60 f_{\mathrm{s}}}{n_{\mathrm{sp}}}\right)
$$

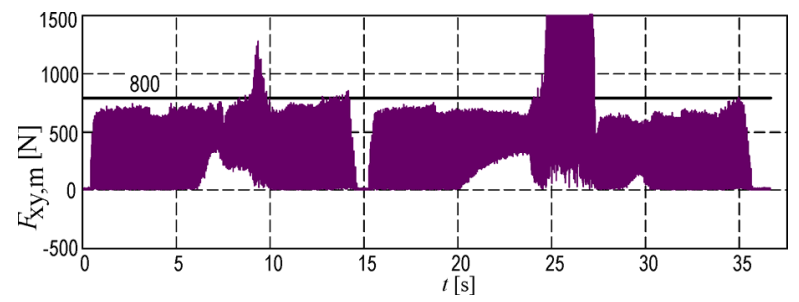

Figure 25. Time series of $F_{x y}$ milling force

Following step is assigning the representative (max.) value of $F_{\mathrm{xy}}$ component to the pair of coordinates $\left(x_{\mathrm{w}}(K), y_{\mathrm{w}}(K)\right)$. Each representative value is obtained as maximum value of $F_{\mathrm{xy}}$ in peroid of one previous spindle revolution:

$$
\begin{aligned}
& F_{\mathrm{xy}(\max )}(K)=\max \left(F_{\mathrm{xy}, \mathrm{m}}(k)\right) ; \\
& k \in\left[1+(K-1) \cdot N_{\mathrm{sp}}, K \cdot N_{\mathrm{sp}}\right]
\end{aligned}
$$

Such processing of recorded time series in this experiment, enables creation of graph (Figure 26) which is very useful in evaluation of presented procedure of feedrate optimization. In this example graph is broken and shaded in toolpath section with chatter.

Based on Figures 25 and 26 several conclusions can be derived. Firstly, it can be noticed that presented off 
line optimisation procedure of the feedrate has satisfying performances.

In most points of the toolpath, specified value of milling force $F_{\text {xy }}$ were achieved with acceptable level of error. ath segments where chatter vibrations were detected. In some sections it is not the case. Two sections are with zero value of $F_{\mathrm{xy}}$. It was caused by zero depth of cut in these sections. It is not possible to reach defined level of $F_{\mathrm{xy}}$, even with maximum feedrate. Another two sections are examples of unstable milling. It is consequence of the fact that described procedure of adaptation and optimization of feedrate does not include dynamic model of the machine and milling process.

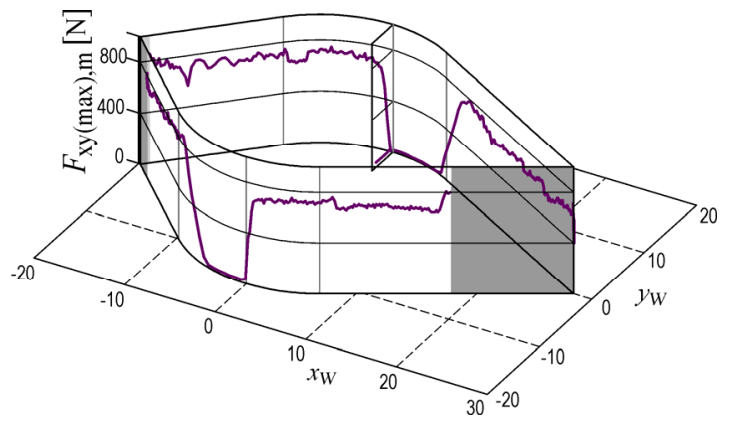

Figure 26. Measured values of $F_{x y}$ calculated for each spindle revolution period along the toolpath

Constant deviation of measured $F_{\mathrm{xy}, \mathrm{m}}$ can be explained by several sources. The first are criteria for optimization of feedrates (Q1-Q3, in Section 5) which are mostly restrictive. Another reason is the fact that prediction procedure of instantaneous milling forces in points of discretized toolpath is based on CWE maps obtained through processing of the Z-map model of the workpiece. Some errors, in that sense, are expected, especially in case of relatively coarse applied resolution of the Z-map base $(0.5 \mathrm{~mm})$. Finally, visible deviations can be explained by the fact that all elements (tool, machine and workpiece) were treated as rigid bodies in presented procedures. Real compliances of these substructures (dynamometer, especially) result in cutting conditions, different from nominal, resulting in change of instantaneous uncut chip thickness.

\section{CONCLUSION}

One successful implementation of procedure of feedrate scheduling is shown in this paper. Set of required functions was developed in Matlab. Whole problem was divided in two phases: off-line adaptation of the feedrate along the toolpath and optimization of feedrates along this path, regarding specific criteria. Experience with program implementation of applied models and experimental verification of the whole procedure point to several conclusions.

Approximation of workpiece volume using Z-map allows its relatively simple manipulation. The lack of this approach is inability to process more complex workpiece shapes. Also, changes in resolution of the Zmap cause rise of processing time with ratio equal to square of their quotient.

Force based feedrate scheduling, using simulation of instantaneous milling forces, simulated on one spindle revolution is expected to achieve better results than MRR based procedures. This was confirmed in experimental verification, in this paper.

Experiment also shows limitations of applied models. One of them is the absence of dynamic model of the machine, tool and process. Thus, proposed procedure can not prevent chatter vibrations in execution of $\mathrm{NC}$ program, modified in this way.

\section{ACKNOWLEDGMENT}

This paper was made in the framework of research in project TR35022 which are suported by the Ministry of Education, Science and Technological Development of the Government of the Republic of Serbia.

\section{REFERENCES}

[1] Altintas, Y., Brecher, C., Weck, M. and Witt, S.: Virtual Machine Tool, Keynote Paper of STC M, Annals of CIRP, Vol. 54, No. 2, pp.651-674, 2005.

[2] Park, H-S., Qi, B., Dang, D-V., Park, D-Y.: Development of smart machining system for optimizing feedrates to minimize machining time, Journal of Computational Design and Engineering No.5, pp. 299-304, 2018.

[3] Lee, H.U. and Cho, D.W.: An intelligent feedrate scheduling based on virtual machining, The International Journal of Advanced Manufacturing Technology, Vol. 22, No. 11, pp. 873-882, 2003.

[4] Lazoglu, I., Khavidaki, S.E.L., Mamedov, A. and Erdim, H.: Process Optimization via Feedrate Scheduling in Milling, in: Laperriere, L., Reinhart, G. (Ed.): Chapter from CIRPEDIA, Berlin Heidelberg, Springer, pp. 979-987, 2014.

[5] Yun, W.S., Ko, J.H., Cho, D.W.: Development of a Virtual Machine Tool - Part 1: Mechanistic Cutting Force Model, Machined Surface Error Model, and Feedrate Scheduling Model, International Journal of the Korean Society of Precision Engineering, Vol. 4, No.2, pp.71-76, 2003.

[6] Kaymakci, M. et al.: Unified cutting force model for turning, boring, drilling and milling operations, International Journal of Machine Tools \& Manufacture, Vol. 54-55, pp. 34-45, 2012.

[7] Adem, K.A.M., Fales, R. and El-Gizawy, A.S.: Identification of cutting force coefficients for the linear and nonlinear force models in end milling process using average forces and optimization technique methods, International Journal of Advanced Manufacturing Technology, Vol. 79, No. 9-12, pp. 1671-1687, 2015.

[8] Lazarevic, D., Jankovic, P., Madic, M., Lazarevic., A.: Robust Conditions for Cutting Force Minimization in Polyamide Turning Process, FME Transactions, Vol. 43, No. 1, pp. 114-118, 2015.

[9] Sequeira, A.A., Ravikantha Prabhu, R., Sriram, N.S., Bhat, T.: Effect of Cutting Parameters on Cutting Force and Surface Roughness of Aluminium Components using Face Milling Process- a Taguchi Approach, Journal of Mechanical and Civil Engineering, Vol. 3, No. 4, pp. 7-13, 2012. 
[10] Popovic, M., Tanovic, Lj. and Ehmann, K.F., Cutting Forces Prediction: the Experimental Identification of Orthogonal Cutting Coefficients, FME Transactions, Vol. 45, No. 1, pp. 459-467, 2017.

[11]Budak, E., Altintas, Y. and Armarego, E.J.A.: Prediction of milling force coefficients from orthogonal cutting data, Transactions of ASME, Journal of Manufacturing Science and Engineering, Vol. 8, No. 2, pp216-224, 1996.

[12] Yussefian, N.Z., Moetakef-Imani, B. and ElMounayri, H. :The prediction of cutting force for boring process, International Journal of Machine Tools \& Manufacture, Vol. 48, No. 12, pp. 13871394, 2008.

[13] Lazar, M.B. and Xirouchakis, P.: Mechanical load distribution along the main cutting edges in drilling, Journal of Materials Processing Technology, Vol. 213, No. 2 , pp. 245-260, 2013.

[14] Kokotovic, B. and Glavonjic, M.: Predicting of milling forces in a virtual manufacturing system, Technical Gazette, Vol. 20, No. 6, pp. 1027-1035, 2013.

[15] Matsumura,T. and Tamura,T.: Cutting force model in milling with cutter runout, Procedia CIRP, Vol. 58, pp. $566-571,2017$.

[16] Wan, M., Zhang, W., Qin G.H. and Tan G.: Efficient calibration of instantaneous cutting force coefficients and runout parameters for general end mills, International Journal of Machine Tools and Manufacture, Vol. 47, No. 11, pp. 1767-1776, 2007.

[17] Lee, S.W. and Nestler, A.: Virtual workpiece: workpiece representation for material removal process, International Journal of Advanced Manufacturing Technology, Vol. 58, No. 5-8, pp 443-463, 2012.

[18] Jang, J.Z., Wang, Q.F., Hung, Z.D. and Chen G.: Cutting area extraction from a Z-map model, International Journal of Advanced Manufactruing Technology, Vol. 33, No. 9-10, pp. 1010-1016, 2007.

[19]Fussel, B.K., Jerard, R.B. and Hemmet, J.G. : Modeling of cutting geometry and forces for 5-axis sculptured surface machining, Computer-Aided Design, Vol. 35, No. 4, pp.333-346, 2003.

[20] Karunakaran, K.P. et al.: Octree-based NC simulation system for optimization of feedrate in milling using instantaneous force model, International Journal of Advanced Manufactruing Technology, Vol. 46, No. 5-8, pp. 465-490, 2009.

[21] Merdol, S.D. and Altintas, Y.:Virtual Cutting and Optimization of Three-Axis milling, International Journal of Machine Tools and Manufacture, Vol. 48, No.10, pp. 1063-1071, 2008.

[22] Kokotovic, B., Zivanovic, S. and Jakovljevic, Z.: Verification of a Procedure for Feedrate Scheduling for Constant Force in 2D Milling Operations, Journal of Production Engineering, Vol. 18, No. 2, pp. 81-84, 2015.

\section{ОПТИМИЗАЦИЈА БРЗИНЕ ПОМОЋНОГ КРЕТАЊА У ЗАХВАТИМА 2.5 ОСНОГ ГЛОДАњА}

\section{Б. Кокотовић, Н. Воркапић}

Представљено истраживање се односи на CNC обраду глодањем раванских контура равним вретенастим глодалима. У раду је представљен скуп функција, потребних за процесирање модела обратка и технолошког програма обраде, са циљем реконструкције тренутне површине обратка захваћене алатом. Изабрана је интерпретација обратка помоћу Z-мапе. Реконструисана мапа захвата, уз претходно одређене специфичне силе резања, довољна је за предвиђање тренутних и репрезентативних сила глодања у тачкама програмиране путање алата. Тиме ce, надаље, омогућава кориговање брзина помоћног кретања у тачкама путање алата и накнадна редискретизација те путање, а све у циљу одржавања предефинисаног нивоа силе глодања. У раду је описан пример експерименталне идентификације специфичних сила резања и пример примене процедура имплементираних у Matlab окружењу, за оптимизацију брзина помоћног кретања. Резултати, добијени у експерименту, искоришћени су за дискусију предности и недостатака примењених модела. 